\title{
Seasonal impact on beach morphology and the status of heavy mineral deposition - central Tamil Nadu coast, India
}

\author{
V JOEviveK* and N CHANDRASEKAR \\ Centre for GeoTechnology, Manonmaniam Sundaranar University, Tirunelveli, India. \\ *Corresponding author. e-mail: vjoevivek@gmail.com
}

The aim of the present research was to investigate the seasonal impact on nearshore beach dynamics and the status of heavy mineral distribution along central Tamil Nadu coast, India. Beach profile measurements were made in 10 profiling sites between Thirukadaiyur and Velankanni on monthly and seasonal basis from January 2011 to July 2012. Using beach profile data, variation in beach width, slope and volumetric changes have been calculated. Beach slope and nearshore wave parameters were used to quantify the longshore sediment transport rate. Beaches between Thirukadaiyur and Karaikkal attained predominant transport rate in northern direction whereas, the rest of the beaches are in southern direction. The seasonal action of wind and wave currents create nearshore bar during northeast (NE) monsoon and frequent berms at tidal zone during southwest (SW) monsoon. Surface sediment samples were collected in each location for quantifying the heavy mineral weight percentage during the period of pre- and postThane cyclone. Sediments were also studied by X-ray diffraction (XRD) to evaluate the changes and occurrence of heavy minerals in beach sands. The XRD results show that sediments in the study area have enriched heavy mineral distribution even after strong cyclonic event. It confirms the redistribution of heavy mineral deposits present in the coast. The results suggested that monsoonal action has influenced the seasonal changes in beach morphology and it does not affect the heavy mineral distribution.

\section{Introduction}

Morphological and sedimentological studies have provided valuable information about the nature of beach dynamics and depositional environment. A complete understanding of beach dynamics requires basic knowledge of the coastal configuration. Beach profile study gives the spatiotemporal variation of the foreshore environment. Many researchers, especially, Delgado and Lloyd (2004) have described the simplest methods for measuring beach profiles. Cooper et al. (2000) briefly explained the history of beach profile measurement and described the theory and analysis of beach profiles. Pickett et al. (1997) described a model for the analysis of beach profile at Bay of Plenty, New Zealand. In the natural beaches, the assumption of constant wave forcing is not satisfied, as accretion and erosion conditions alternate over time (Quartel et al. 2008) and the beach response to wave forcing is not instantaneous (Wright et al. 1985). Regional beach profile study has been conducted by Saxena et al. (1976), Anil Cherian (2003), Rajamanickam (2006), Antonio and Seelam (2008) and Sheik Mujabar (2010) along southeast coast of India.

Coastal geomorphology not only includes the beach topography but also includes the wave

Keywords. Sediment transport; placer deposits; heavy minerals; beach profile; morphodynamic state; India. 
process, sediment transport and nearshore dynamics. The wave parameters such as breaker wave height, breaker angle, longshore current velocity and surf zone width play a vital role to control the nearshore processes. The earlier studies (Bijker 1971; Chandramohan et al. 1994; Tillotsen and Komar 1997; Sanil Kumar et al. 2002) have revealed the importance of wave parameters to examine the sediment transport rate and surf zone dynamics. In the present study, visual and field measurements were made to measure the wave parameters along the central coast of Tamil Nadu (figure 1).

The east coast of India, especially the central Tamil Nadu coast has witnessed several morphodynamic activities. The coastal region experiences three seasonal actions in a year such as NE monsoon (October-January), SW monsoon (June-September), and non-monsoon (FebruaryMay). Figure 2 illustrates the seasonal response on wave height, wave period and their direction. The wave rose diagram has been prepared based on standard procedure described in Indian wave atlas, published by NIO, Goa. The higher wave height is noticed during $\mathrm{NE}$ monsoon and waves become calm during non-monsoon season.

According to the Wright and Short morphodynamic state model (Wright and Short 1984), beaches in the present study area have reflective state during the SW monsoon, dissipative state during the NE monsoon and intermediate state during non-monsoon season. Textural and morphodynamic state of the central Tamil Nadu coast is shown in table 1 . The sediments present in the study area are mostly unimodel and very well sorted. The mean size of beach sediments ranges from medium-to-very fine sand. Sorting results have shown that samples are very close to the median grain size. The coarse skewed and leptokurtic properties of beach sediments reveal that beach sands are symmetric in structure. Moreover, the beaches are enriched with black sands and heavy minerals (Chandrasekar 1992). Literature studies have shown that major placer deposits such as Garnet, Ilmenite, Rutile,

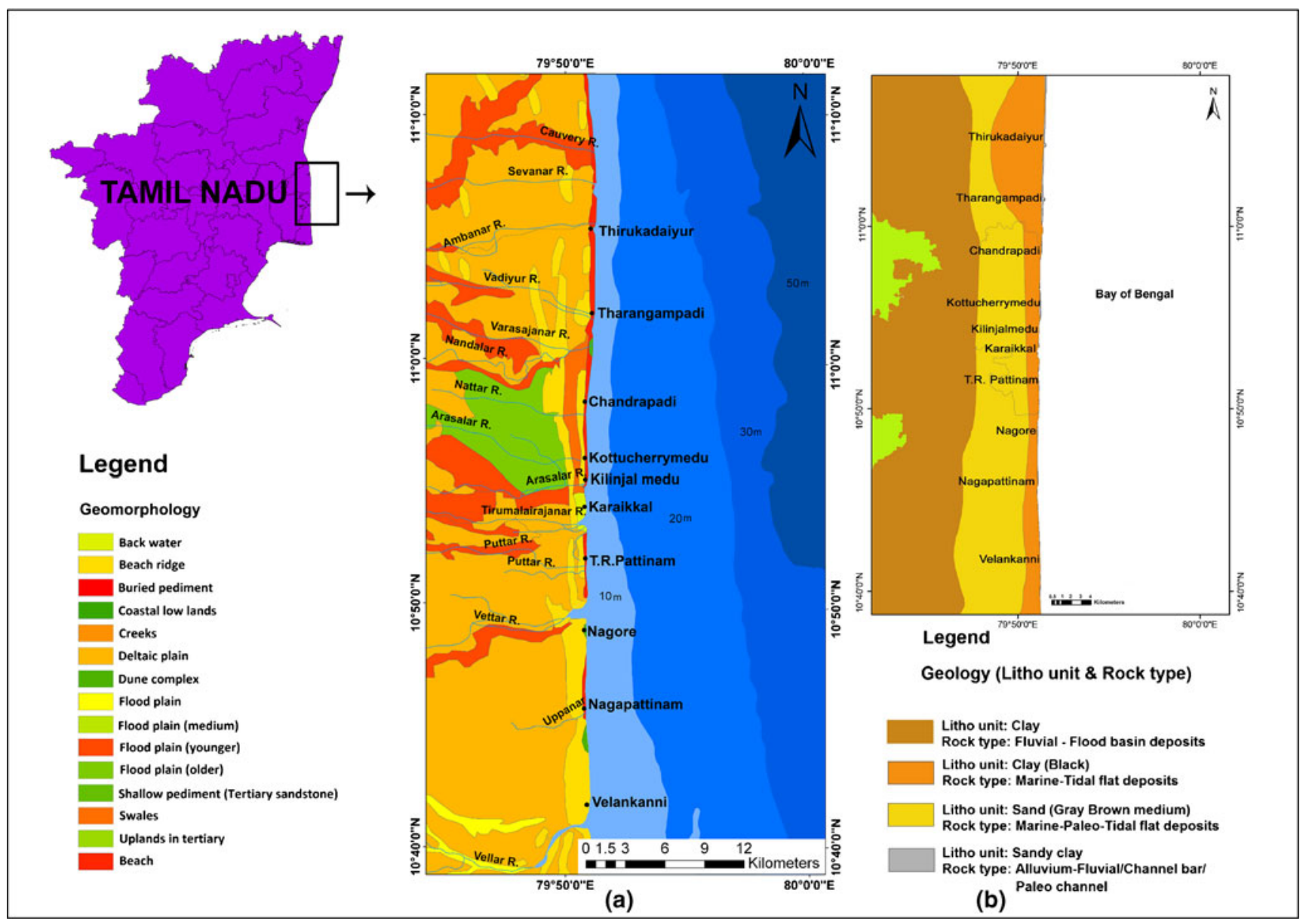

Figure 1. (a) Location and geomorphology map of the study area and (b) geology map of the study area. 


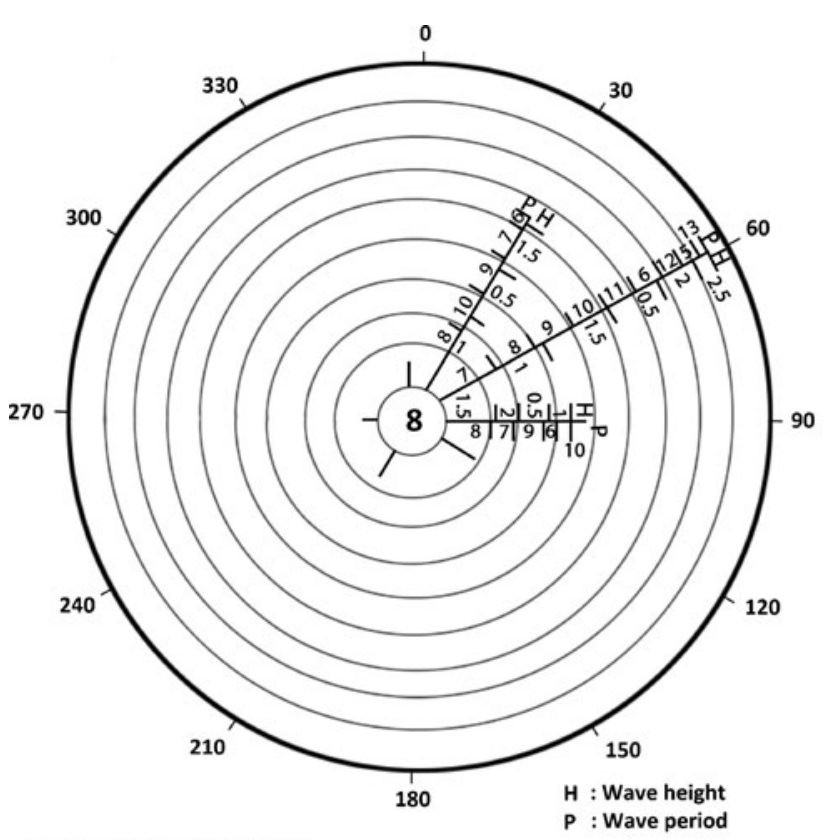

Average wave height: $1.04 \mathrm{~m}$ Average wave period: $7 \mathrm{sec}$

January 2011

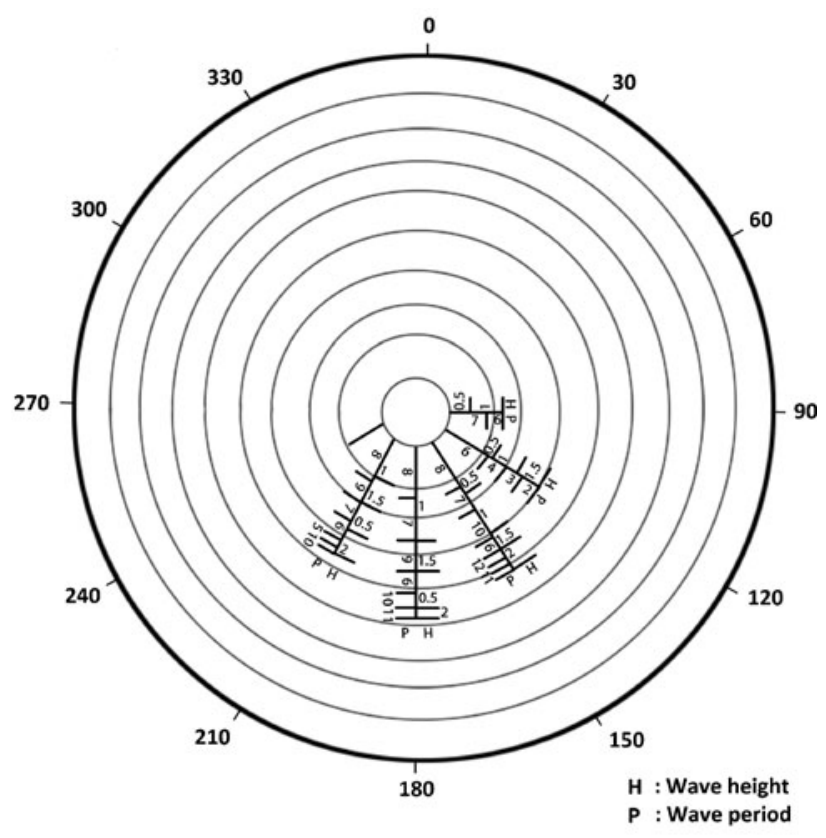

Average wave height: $0.784 \mathrm{~m}$ Average wave period: $8 \mathrm{sec}$
April 2011

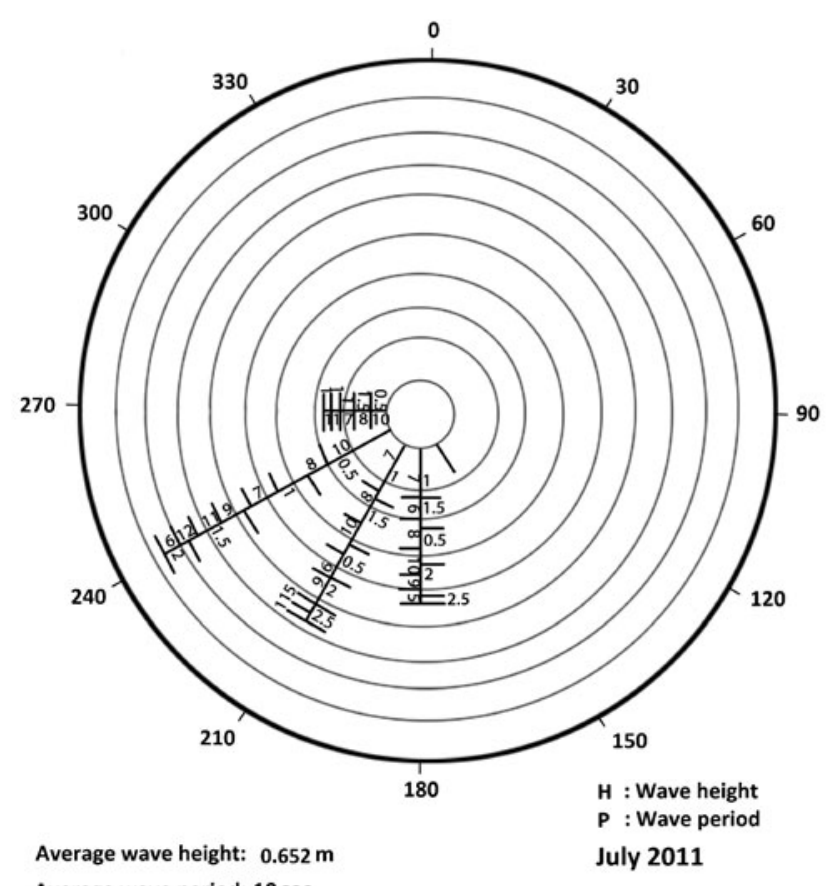
Average wave period: $10 \mathrm{sec}$
July 2011

C

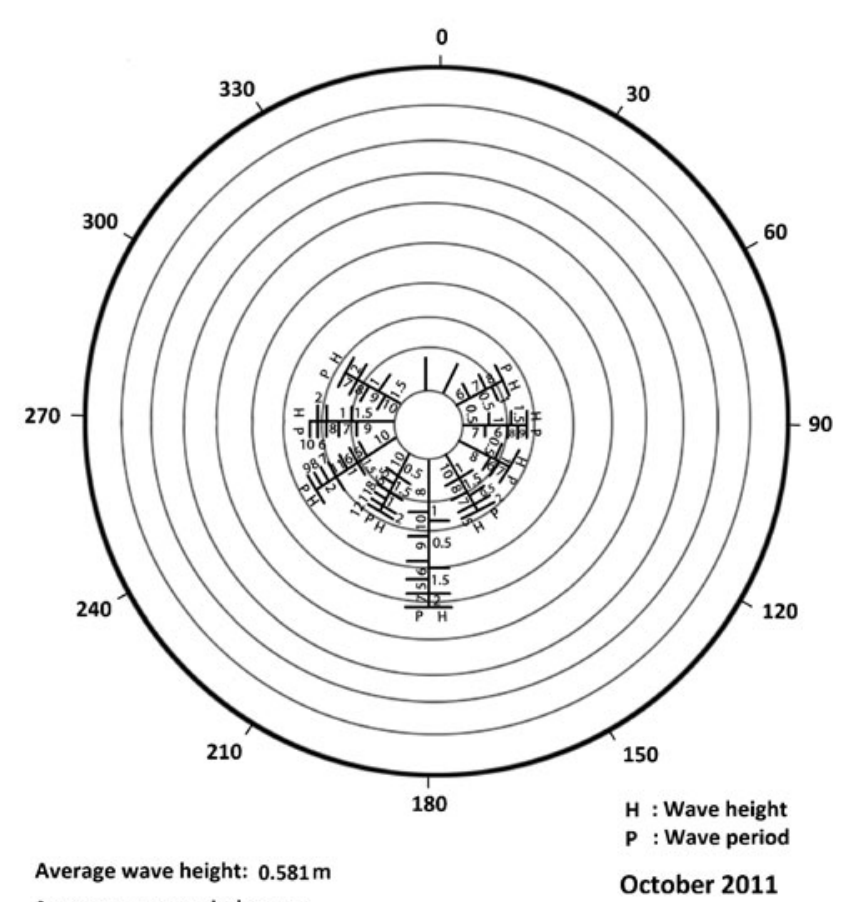

d

Figure 2. Wave rose diagram describing seasonal changes in wave height and wave period.

Zircon, Monazite and Silliimanite are present in the central Tamil Nadu coast (Chandrasekar 1992; Rajamanickam 1992; Mohan and Rajamanickam 2000; Chandrasekar and Rajamanickam 2002; Rajamanickam and Angusamy 2005; Loveson et al.
2008; Suresh Gandhi and Solai 2010; Suresh Gandhi et al. 2011). This coast is very sensitive to hydrodynamic processes, sediment supply and beach dynamics. Therefore, an attempt has been made to study the seasonal impact on beach 
Table 1. Textural features and morphodynamic state of the central Tamil Nadu coast.

\begin{tabular}{|c|c|c|c|c|c|c|}
\hline \multirow[b]{2}{*}{ Sl. no. } & \multirow[b]{2}{*}{ Station } & \multicolumn{4}{|c|}{ Textural features } & \multirow{2}{*}{$\begin{array}{c}\text { Morphodynamic } \\
\text { state }^{*}\end{array}$} \\
\hline & & $\overline{\text { Mean }}$ & Sorting & Skewness & Kurtosis & \\
\hline 1 & Tirukadaiyur & 2.16 & 2.18 & -0.13 & 41.21 & Dissipative \\
\hline 2 & Tharangampadi & 2.08 & 2.05 & -0.19 & 30.25 & Intermediate \\
\hline 3 & Chandrapadi & 2.17 & 2.13 & -0.12 & 32.53 & Dissipative \\
\hline 4 & Kottucherrymedu & 2.29 & 2.28 & -0.09 & 39.91 & Dissipative \\
\hline 5 & Kilinjalmedu & 2.36 & 2.24 & -0.1 & 55.49 & Intermediate \\
\hline 6 & Karaikal & 2.69 & 2.69 & -0.03 & 61.25 & Intermediate \\
\hline 7 & TR Pattinam & 2.14 & 2.08 & -0.06 & 32.51 & Intermediate \\
\hline 8 & Nagore & 2.16 & 2.11 & -0.08 & 29.22 & Dissipative \\
\hline 9 & Nagapattinam & 2.51 & 2.5 & -0.01 & 49.76 & Dissipative \\
\hline 10 & Velankanni & 2.52 & 2.51 & -0.11 & 56.72 & Dissipative \\
\hline
\end{tabular}

*According to the Wright and Short morphodynamic state model (Wright and Short 1984).

morphology and the status of heavy mineral deposition along the central coast of Tamil Nadu.

\section{Area of investigation}

\subsection{Location}

The coastal stretch of the present study area covers a total of $51 \mathrm{~km}$ which is located between Thirukadaiyur in the north and Velankanni in the south. It extends between $11^{\circ} 04^{\prime} \mathrm{N}-79^{\circ} 51^{\prime} \mathrm{E}$ and $10^{\circ} 40^{\prime} \mathrm{N}-79^{\circ} 51^{\prime} \mathrm{E}$. The shoreface experiences convergence wave action. Moreover, the area is traversed by complex river channels and coastal construction (harbour, jetties). The study area occupies a major portion of the Cauvery river consisting of narrow wetlands split by various river branches. The Vellar, Puliar, Thirumalairajanar, Arasalar, Nallar, Virasolanar are some of the other distributaries, supporting the minor river irrigation system. The location map along with coastal geomorphology is presented in figure 1(a). The geomorphological features were derived from district resource map 1996 with 1:50000 scales, published by GSI.

\subsection{Geology}

Geological features of the present study area were obtained from GSI published map 1996 with 1:50000 scale and shown in figure $1(\mathrm{~b})$. The eastern part of the study area is covered by alluvium. The age of the outcrops in the study area is from Late Jurassic to Recent. Major Litho units are clay, clay black and alluviam sandy clay. Tharangampadi depression is located to the south of Kumbakonam-Shiyali ridge. It is tracked in the south upto the Karaikkal high and extends into the offshore towards the east. Karaikkal high is a relatively small feature, most of which appears to lie in the offshore. It is aligned nearly ENE-WSW.

\subsection{Coastal geomorphology}

The studyof coastal landforms is one of the fascinating areas of geomorphological research. The coastal tract of central Tamil Nadu consists of an upland plain (denudational), flood plain (fluvial), deltaic plain and coastal plain (marine) (Chandrasekar 1992; Mohan et al. 2000). The relief of the north and south Nagapattinam coast is disturbed by estuaries, lagoons and creeks. Beach ridges present along the coast lie almost parallel to the present shoreline. The width of the beach ridges vary from 45 to $150 \mathrm{~m}$. The presence of beach ridges along the coast indicates the shoreline is propagating towards the sea (Revathy et al. 2002), since Nagapattinam is located between two big beach ridge systems, largely affected by heavy rainfall and storm surge during the NE monsoon. A series of sand dunes occur parallel to the coast around TR Pattinam, Karaikkal, Kottucherrymedu, Kilinjalmedu and Chandrapadi. Dunes are located very close to the beaches with a height of $8 \mathrm{~m}$. Vegetation and settlements are present in the dunes in a stabilized condition. The beach sediments are mainly composed of quartz, feldspar along with heavy minerals (Chandrasekar 1992).

\section{Materials and methods}

\subsection{Beach profile survey}

The beach profile survey was carried out on monthly and seasonal basis from January 2011 to July 2012. Totally, 10 stations with an approximate interval of $5 \mathrm{~km}$ were fixed between Thirukadaiyur and Velankanni. Depending upon the river confluence, delta mouth and swamp, the profiling sites have been varied but do not exceed $4 \mathrm{~km}$. The slope of each profile segment is measured using total station (Trimble@ M3). In each station, slope is measured at $2-\mathrm{m}$ interval from 

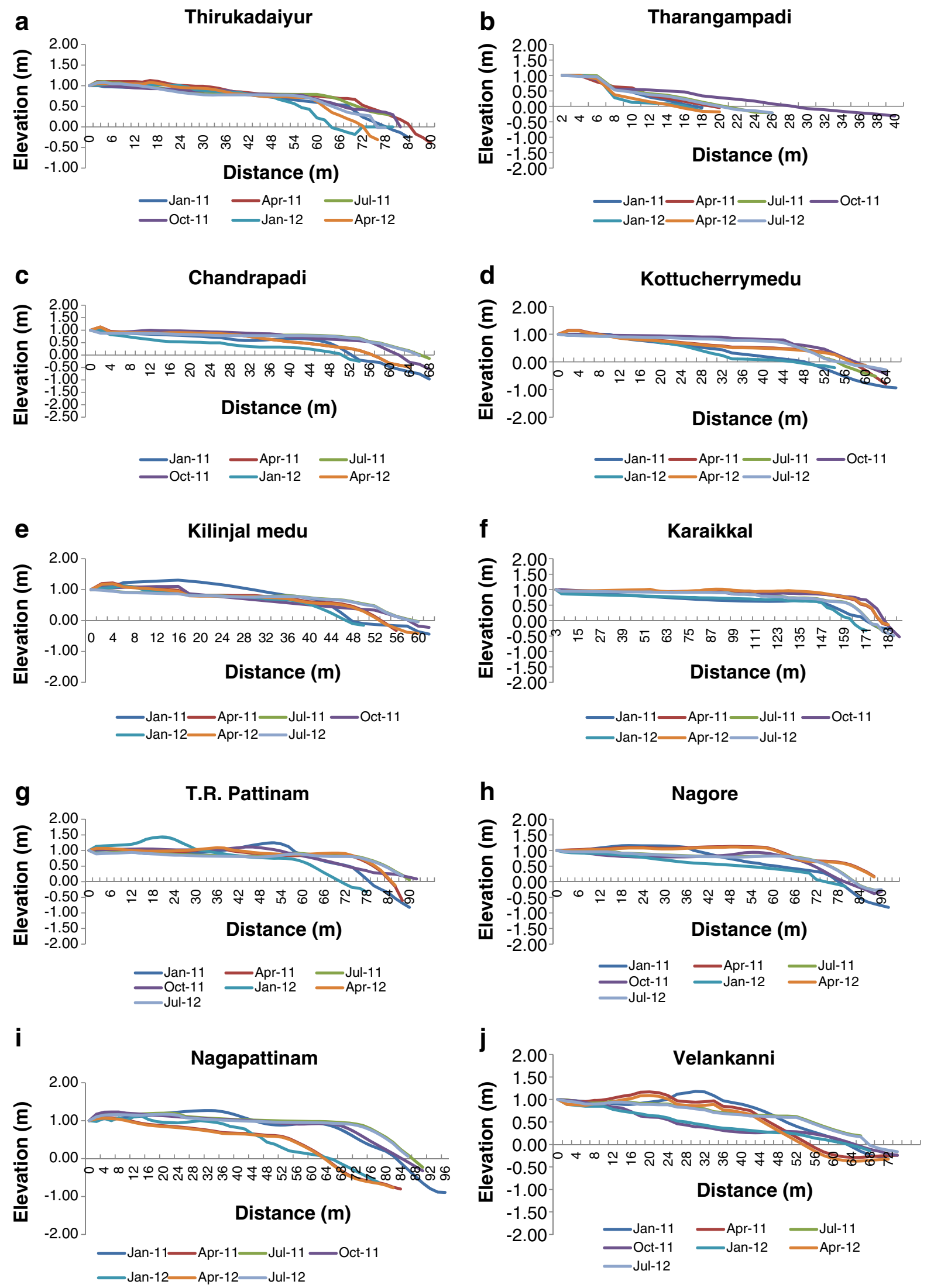

Figure 3. (a-j) Seasonal variation in beach profiles along the study area. 
Table 2. Seasonal basis beach width variation along the study area.

\begin{tabular}{|c|c|c|c|c|c|c|c|}
\hline \multirow[b]{2}{*}{ Station } & \multicolumn{7}{|c|}{ Beach width $(\mathrm{m})$} \\
\hline & Jan-11 & Apr-11 & Jul-11 & Oct-11 & Jan-12 & Apr-12 & Jul-12 \\
\hline Thirukadaiyur & 83 & 89 & 79 & 80 & 69 & 76 & 78 \\
\hline Tharangampadi & 18 & 20 & 26 & 40 & 18 & 20 & 26 \\
\hline Chandrapadi & 63 & 59 & 64 & 64 & 53 & 60 & 62 \\
\hline Kottucherrymedu & 66 & 64 & 63 & 65 & 54 & 61 & 63 \\
\hline Kilinjalmedu & 61 & 56 & 58 & 61 & 49 & 59 & 58 \\
\hline Karaikkal & 187 & 181 & 178 & 187 & 171 & 176 & 178 \\
\hline TR Pattinam & 89 & 88 & 90 & 91 & 78 & 84 & 88 \\
\hline Nagore & 91 & 88 & 86 & 89 & 81 & 88 & 90 \\
\hline Nagapattinam & 96 & 83 & 88 & 87 & 73 & 81 & 86 \\
\hline Velankanni & 74 & 76 & 68 & 72 & 67 & 71 & 73 \\
\hline
\end{tabular}

Table 3. Seasonal basis beach slope variation along the study area.

\begin{tabular}{|c|c|c|c|c|c|c|c|}
\hline \multirow[b]{2}{*}{ Station } & \multicolumn{7}{|c|}{ Nearshore beach slope (in rad) } \\
\hline & Jan-11 & Apr-11 & Jul-11 & Oct-11 & Jan-12 & Apr-12 & Jul-12 \\
\hline Thirukadaiyur & 0.1084 & 0.1502 & 0.1641 & 0.1447 & 0.1002 & 0.107 & 0.1052 \\
\hline Tharangampadi & 0.1043 & 0.1405 & 0.0961 & 0.1014 & 0.1052 & 0.1303 & 0.1607 \\
\hline Chandrapadi & 0.1514 & 0.2116 & 0.1352 & 0.2008 & 0.1607 & 0.1394 & 0.1304 \\
\hline Kottucherrymedu & 0.1386 & 0.1354 & 0.1407 & 0.1743 & 0.1102 & 0.1622 & 0.2424 \\
\hline Kilinjal medu & 0.159 & 0.1506 & 0.1463 & 0.1462 & 0.1506 & 0.1776 & 0.1912 \\
\hline Karaikkal & 0.111 & 0.1563 & 0.1416 & 0.1886 & 0.1103 & 0.1564 & 0.2269 \\
\hline TR Pattinam & 0.127 & 0.1304 & 0.121 & 0.147 & 0.1202 & 0.1138 & 0.1455 \\
\hline Nagore & 0.1217 & 0.1607 & 0.1464 & 0.1106 & 0.1253 & 0.1447 & 0.181 \\
\hline Nagapattinam & 0.131 & 0.1102 & 0.1715 & 0.1228 & 0.1658 & 0.17 & 0.1708 \\
\hline Velankanni & 0.1015 & 0.1556 & 0.1367 & 0.0975 & 0.1102 & 0.1011 & 0.0851 \\
\hline
\end{tabular}

backshore to foreshore region. The measured data are adjusted to the bench mark of the area in the survey of India toposheet and the mean sea level is based on the chart datum (chart no. 3007, scale 1:35,000, year 2010) published by NHO, Dehradun. A simple visual basic model BEACH developed by Chandrasekar and Sheik Mujabar (2010) has been utilized for beach profile analysis.

\subsection{Measuring nearshore parameters}

The nearshore wave parameters were measured during the same period along the ten profile sites. The breaker wave height $(\mathrm{Hb})$ was measured using a calibrated staff. Two persons measured crest and trough of the breaker waves and significant wave height was obtained by averaging the recorded wave height of twenty successive waves. The direction of breaker locator was fixed visually using GPS and the digital compass. At the breaker locator, base of the rope was tied with boat edge and other side set to free floating. The breaker angle was measured by length of deviation in the rope observed by total station. The longshore current velocity measured by the buoyant plate travelled the distance in $2 \mathrm{~min}$ beyond the surf zone. The surf zone width was measured as the distance between boat and total station.

\subsection{Heavy mineral separation}

Surface sediment samples were collected in each profile site during the same period seasonally. Three samples were collected at each site from low tide, high tide and berm region which are not affected by plastic and other debris. The dried sediment samples were pre-treated to remove the clay, organic and shelly materials. The treated samples were sieved by mechanical sieve shaker in a $1 / 4 \phi$ interval (ranging from 1.25 to $4 \phi$ ). The textural features (mean, standard deviation, skewness and kurtosis) of sieved data were computed based on standard statistical procedure (Folk and Ward 1957). Heavy and light minerals in the respective fractions were separated by bromoform (specific gravity 2.89 and molecular weight $252.73 \mathrm{~g} / \mathrm{mol}$ ) as per the standard procedure suggested by Milner (1962). 
Table 4. Seasonal basis beach sediment volume along the study area.

\begin{tabular}{|c|c|c|c|c|c|c|c|}
\hline \multirow[b]{2}{*}{ Station } & \multicolumn{7}{|c|}{ Beach sediment volume $\left(\mathrm{m}^{3}\right)$} \\
\hline & $\overline{\text { Jan-11 }}$ & Apr-11 & Jul-11 & Oct-11 & Jan-12 & Apr-12 & $\overline{\text { Jul-12 }}$ \\
\hline Thirukadaiyur & 52.49 & 58.26 & 58.72 & 57.9 & 54.66 & 54.22 & 58.54 \\
\hline Tharangampadi & 6.92 & 7.39 & 8.33 & 13.29 & 5.12 & 5.21 & 7.37 \\
\hline Chandrapadi & 27.75 & 35.13 & 44.74 & 39.55 & 20.89 & 34.95 & 44.62 \\
\hline Kottucherrymedu & 15.30 & 28.46 & 38.81 & 41.93 & 21.35 & 34.19 & 40.55 \\
\hline Kilinjalmedu & 43.98 & 38.30 & 41.16 & 35.92 & 37.25 & 36.48 & 40.44 \\
\hline Karaikkal & 59.38 & 83.94 & 74.12 & 71.34 & 72.26 & 86.06 & 70.02 \\
\hline TR Pattinam & 62.24 & 64.51 & 67.39 & 75.09 & 69.71 & 71.75 & 65.31 \\
\hline Nagore & 52.74 & 76.63 & 62.33 & 59.73 & 45.79 & 75.25 & 62.02 \\
\hline Nagapattinam & 67.06 & 37.08 & 76.84 & 74.06 & 28.29 & 36.87 & 76 \\
\hline Velankanni & 48.41 & 41.66 & 47.15 & 28.16 & 32.04 & 36.15 & 46.18 \\
\hline
\end{tabular}

\section{Results}

\subsection{Beach morphology}

The data obtained from January 2011 to July 2012 yield an extensive dataset that could be used to determine the seasonal impact on beach morphology (figure 3). The cross-shore beach profile has shown that ridge and runnel systems are present in the coast during the period between NE and non-monsoon. The ridge and runnel pattern is formed in the foreshore region due to interaction of waves, tides, currents and beach topography. However, the runnels become almost flat due to sand accumulation by strong onshore winds during the rest of the period.

The process of seasonal wave action is shifting the sand materials from berm to bar and back again (Bascom 1951). The variation in the berm and beach slope indicates that excess of wave energy emanated during NE monsoon removing the material from the berm crest and carrying it towards the sea. During the cyclone surge, seaward flowing bottom currents remove the lesser sediments from the beach face and move it towards the sea. At the same time, surging waves create a series of abandoned berms at the backshore region (figure 3i). The lower wave energy during SW and non-monsoon seasons remove the lesser amount of sediments at the bottom of the beach in backrush and drop some sand during uprush thus resulting in deposition. During the period of storm surge, the beaches attain a flat terrace at low tide region (figure 3). This is due to wave backrush, which removes the foreshore sediments and drops it in nearshore region forming a surf zone bar.

The relation between beachface slope and sediment size variation is well established by Bascom (1951). Sharp crest and flat berm top at Karaikkal beach have confirmed that moderate grain size (ranging between 1.25 and $2.50 \varphi$ ) are present in the beach. Beachface slope from Nagore to Velankanni correspond to wave height ranging from 1.0-1.25 m, implying that fine grained sediments with dissipative state prevailed in the coast. The presence of medium-to-very fine sands in the beach indicates that beachface slope attains equilibrium condition through onshore/offshore sediment transport (Heitor and Cristina 2010). The bi-model nature of grain size distribution along the beach profile clearly indicates the gradual shift in sediment volume and heavy mineral percentage.

\subsubsection{Beach width}

Beach width variation in SW to NE monsoon (table 2) indicates that beaches of Nagapattinam, TR Pattinam, Karaikkal, Kottucherrymedu, Chandrapadi, Tharangampadi are eroding considerably whereas, the beaches of Velankanni, Nagore, Kilinjalmedu and Thirukadaiyur show accretion trend. Within a short period of time (September 2011December 2011), Tharangampadi beach attains significant variation due to presence of coastal structures (man-made constructions) that obstruct the movement of littoral sand. The sediments are transported by uprush that creates numerous berms at backshore region. These sediment deposits form a beach ridge due to repeated aeolian process by wave currents. Beach width for July 2011 and July 2012 reflect the sediment rework by seasonal act and continuous wave action.

\subsubsection{Beach slope}

The profile variation of beach topography revealed that steep slope is associated with accretion and flat slope is associated with erosion. The beach slope is presented in radian units (table 3 ). During the period between SW and NE monsoon, the slope face is decreased considerably. This is due to seasonal changes in wave action transporting the sediments from berm to nearshore and formation of a longshore bar. The slope of Karaikkal beach clearly reflects the bar-berm variation during monsoon periods. The maximum steep slope is observed at Karaikkal beach (0.1886 rad) during 
Table 5. Seasonal variation on breaker wave height, longshore current and surf zone width.

\begin{tabular}{|c|c|c|c|c|c|c|c|}
\hline Station & Jan-11 & Apr-11 & Jul-11 & Oct-11 & Jan-12 & Apr-12 & Jul-12 \\
\hline \multicolumn{8}{|c|}{ Breaker wave height $\left(H_{b}\right)(\mathrm{m})$} \\
\hline Thirukadaiyur & 0.88 & 0.68 & 0.58 & 0.56 & 0.97 & 0.73 & 0.51 \\
\hline Tharangampadi & 0.82 & 0.72 & 0.54 & 0.64 & 0.95 & 0.76 & 0.47 \\
\hline Chandrapadi & 0.74 & 0.94 & 0.57 & 0.66 & 0.96 & 0.73 & 0.5 \\
\hline Kottucherrymedu & 0.94 & 0.74 & 0.55 & 0.76 & 1.02 & 0.85 & 0.42 \\
\hline Kilinjalmedu & 0.88 & 0.78 & 0.53 & 0.66 & 1.04 & 0.84 & 0.46 \\
\hline Karaikkal & 0.83 & 0.68 & 0.66 & 0.65 & 0.98 & 0.82 & 0.78 \\
\hline TR Pattinam & 0.92 & 0.75 & 0.46 & 0.61 & 0.94 & 0.73 & 0.39 \\
\hline Nagore & 0.92 & 0.74 & 0.68 & 0.74 & 0.96 & 0.79 & 0.61 \\
\hline Nagapattinam & 0.98 & 0.86 & 0.59 & 0.61 & 1.03 & 0.75 & 0.52 \\
\hline Velankanni & 0.7 & 0.67 & 0.6 & 0.62 & 0.96 & 0.76 & 0.53 \\
\hline \multicolumn{8}{|c|}{ Longshore current velocity $(V)(\mathrm{m} / \mathrm{s})$} \\
\hline Thirukadaiyur & 0.111 & -0.167 & -0.150 & -0.182 & 0.27 & -0.09 & -0.16 \\
\hline Tharangampadi & 0.216 & -0.161 & -0.133 & -0.229 & 0.23 & -0.19 & -0.13 \\
\hline Chandrapadi & 0.163 & -0.166 & -0.120 & -0.190 & 0.25 & -0.25 & -0.11 \\
\hline Kottucherrymedu & 0.168 & -0.150 & -0.139 & -0.123 & 0.27 & -0.24 & -0.14 \\
\hline Kilinjalmedu & 0.177 & -0.183 & -0.120 & -0.214 & 0.28 & -0.24 & -0.15 \\
\hline Karaikkal & 0.099 & -0.139 & -0.149 & -0.261 & 0.39 & -0.20 & -0.13 \\
\hline TR Pattinam & 0.172 & -0.161 & -0.143 & -0.161 & 0.39 & -0.15 & -0.12 \\
\hline Nagore & 0.214 & -0.175 & -0.134 & -0.176 & 0.25 & -0.24 & -0.14 \\
\hline Nagapattinam & 0.301 & -0.238 & -0.114 & -0.189 & 0.33 & -0.22 & -0.15 \\
\hline Velankanni & 0.239 & -0.128 & -0.114 & -0.140 & 0.28 & -0.20 & -0.12 \\
\hline \multicolumn{8}{|l|}{ Surf zone width (m) } \\
\hline Thirukadaiyur & 57 & 31 & 29 & 37 & 64 & 42 & 18 \\
\hline Tharangampadi & 64 & 35 & 48 & 58 & 67 & 38 & 24 \\
\hline Chandrapadi & 40 & 21 & 28 & 30 & 44 & 32 & 34 \\
\hline Kottucherrymedu & 43 & 38 & 35 & 33 & 66 & 34 & 31 \\
\hline Kilinjalmedu & 39 & 35 & 28 & 41 & 49 & 30 & 25 \\
\hline Karaikkal & 60 & 33 & 31 & 32 & 65 & 32 & 25 \\
\hline TR Pattinam & 50 & 40 & 32 & 39 & 58 & 39 & 34 \\
\hline Nagore & 49 & 31 & 27 & 55 & 54 & 34 & 28 \\
\hline Nagapattinam & 46 & 44 & 24 & 46 & 41 & 32 & 25 \\
\hline Velankanni & 58 & 29 & 33 & 59 & 58 & 48 & 28 \\
\hline
\end{tabular}

Note: $(-)$ sign indicates northern direction and $(+)$ sign indicates southern direction.

the SW monsoon and gentle slope is recorded at Velankanni $(0.0851 \mathrm{rad})$ for all the seasons. It is evident that the southern part of the central Tamil Nadu coast has low energy wave action.

\subsubsection{Beach sand volume}

The sediment volume along the different beaches undergoes typical seasonal changes due to hydrodynamic conditions. Sand volume is increased in the SW monsoon period and decreased in $\mathrm{NE}$ monsoon period (table 4). Among the beaches, Nagapattinam exhibits more volumetric changes in NE monsoon due to Thane cyclone. During this period, sediments are transported into foreshore, resulting in abundant longshore bars being formed at nearshore. The post-storm process creates creek formation at Nagapattinam due to low lands present in the area. Thereby the coast is prone to risk from storm surge flooding. On these beaches rhythmic bar-beach morphology is observed which indicates nearshore circulation during calm days. It is possible that many strong currents are present to recycle the sediments and favour the deposition of heavy minerals.

\subsection{Nearshore processes}

Nearshore measurement is an important phase of coastal monitoring that delivers the wave environment of the coastal zone. Wave parameters, particularly, breaker wave height, breaker angle, longshore current velocity and surf zone width have strong convergence force to direct the nearshore processes. Methods used to quantify nearshore wave parameters are described earlier in the methodology section. The results 

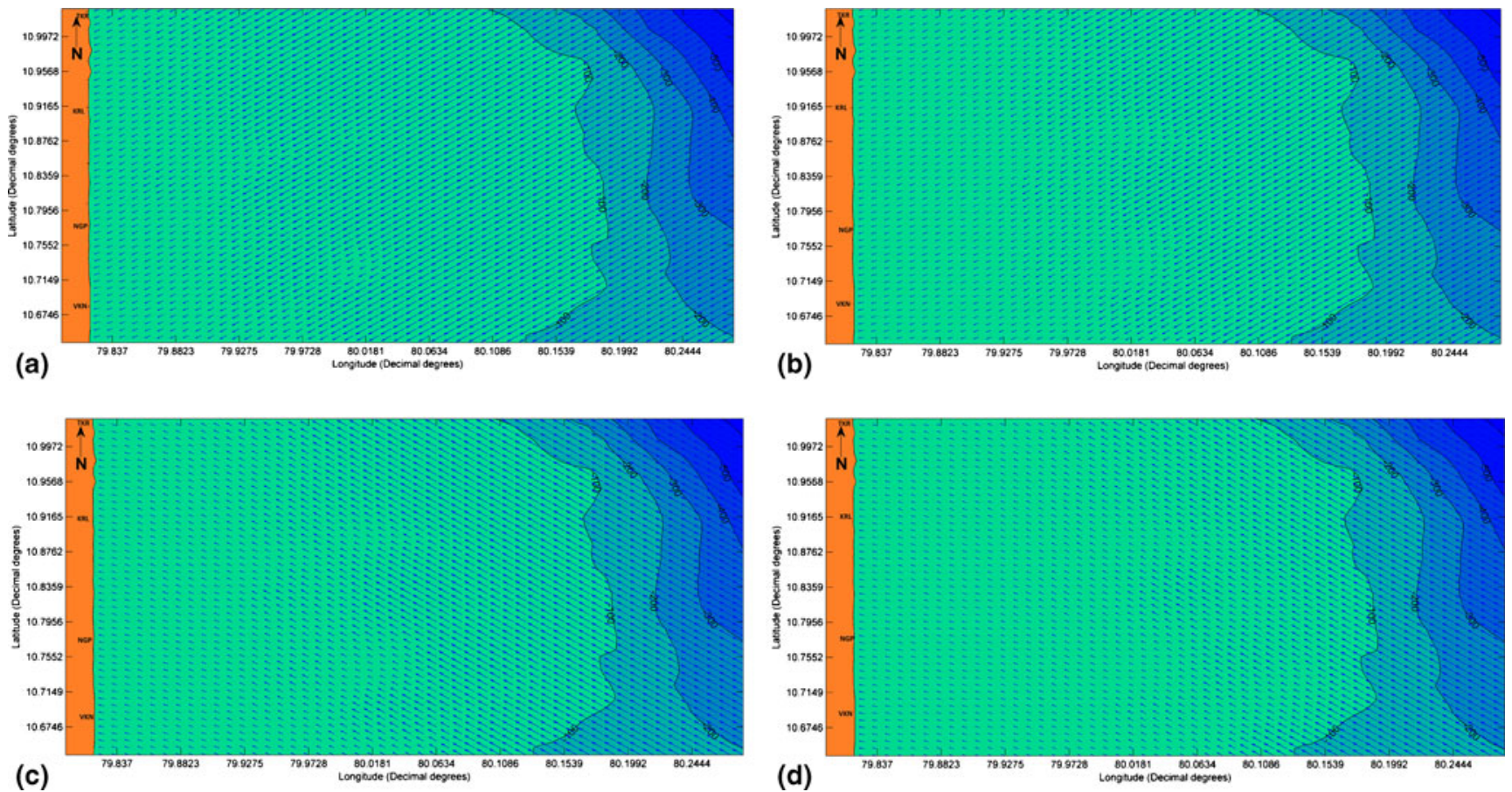

Figure 4. Wave refraction diagram (Bathymetric contours are in metre). (a) $6 \mathrm{sec}$ wave period during NE monsoon, (b) 8 sec wave period during NE monsoon, (c) 8 sec wave period during SW monsoon, (d) 10 sec wave period during SW monsoon (stations - TKR: Thirukadaiyur, KRL: Karaikkal, NGP: Nagapattinam, VKN: Velankanni) (after Chandrasekar 1992).

were interpreted based on Longuet-Higgins (1970) and Galvin (1963), Shoreline protection manual (1984) and Coastal Engineering Manual (2002). Table 5 illustrates the maximum wave height $(1.25 \mathrm{~m})$ recorded at Karaikkal beach and minimum $(0.63 \mathrm{~m})$ at Velankanni. The prolong period of wide range of wave heights during summer is prone to the development of strong rip currents and replenishes the sediments to the beaches. The coast produces surging breakers more during NE monsoon than during the rest of the period.

The breaker angle is projected towards the south during NE monsoon whereas it is shifted towards the north for the rest of the period. The longshore current propagates towards north between March and October 2011. The maximum magnitude of longshore current $(0.41 \mathrm{~m} / \mathrm{s})$ towards south is observed at Karaikkal and Nagapattinam during January 2012. It implies that higher sediment transport takes place during NE monsoon. The surf zone width varies between 31 and $91 \mathrm{~m}$. The surf zone width increases during NE monsoon due to the presence of longshore bar at nearshore region.

Nearshore waves approach the coast predominantly in NE and SW directions. Wave period mostly prevails for about $6-8$ sec during the $\mathrm{NE}$ monsoon and $8-10 \mathrm{sec}$ during the rest of the period. Littoral currents are moderate to strong during SW monsoon and variable during NE monsoon. Chauhan (1995) inferred that NE and SW monsoon controls the longshore sediment transport along the east coast of India. Hence, wave refraction pattern have been drawn for $\mathrm{NE}\left(45^{\circ}\right)$ and SW $\left(135^{\circ}\right)$ monsoon with different wave periods. Figure 4 shows a quantitative picture of littoral currents prevailing in the cast. It reflects the dominance of the low energy environment. However, the zone of convergence favours the deposition of heavy mineral placer along the beaches. During NE monsoon, the coast expresses sporadic enhancements in the wind and wave climate due to occurrence of the cyclone/storm. The littoral current direction together with the submerged ridges has also been confirmed by orientation in arrow symbol (figure 4). It indicates that submerged ridges play a vital role in the process of beach morphology along the present study area.

\subsection{Longshore sediment transport}

The littoral zone is the most dynamic environment along the coast where constant mobility of sediment is observed. The phenomenon of longshore sediment transport plays a vital role in the studies related to beach erosion, shoreline migration, harbour design and sedimentation, etc. Many researchers especially, King (1972, 1974), Willis (1980), Shore Protection Manual (1984), Walton and Bruno (1989), Chandrasekar (1992) and Anil Cherian (2003) have developed and used empirical relation to estimate longshore sediment transport. 


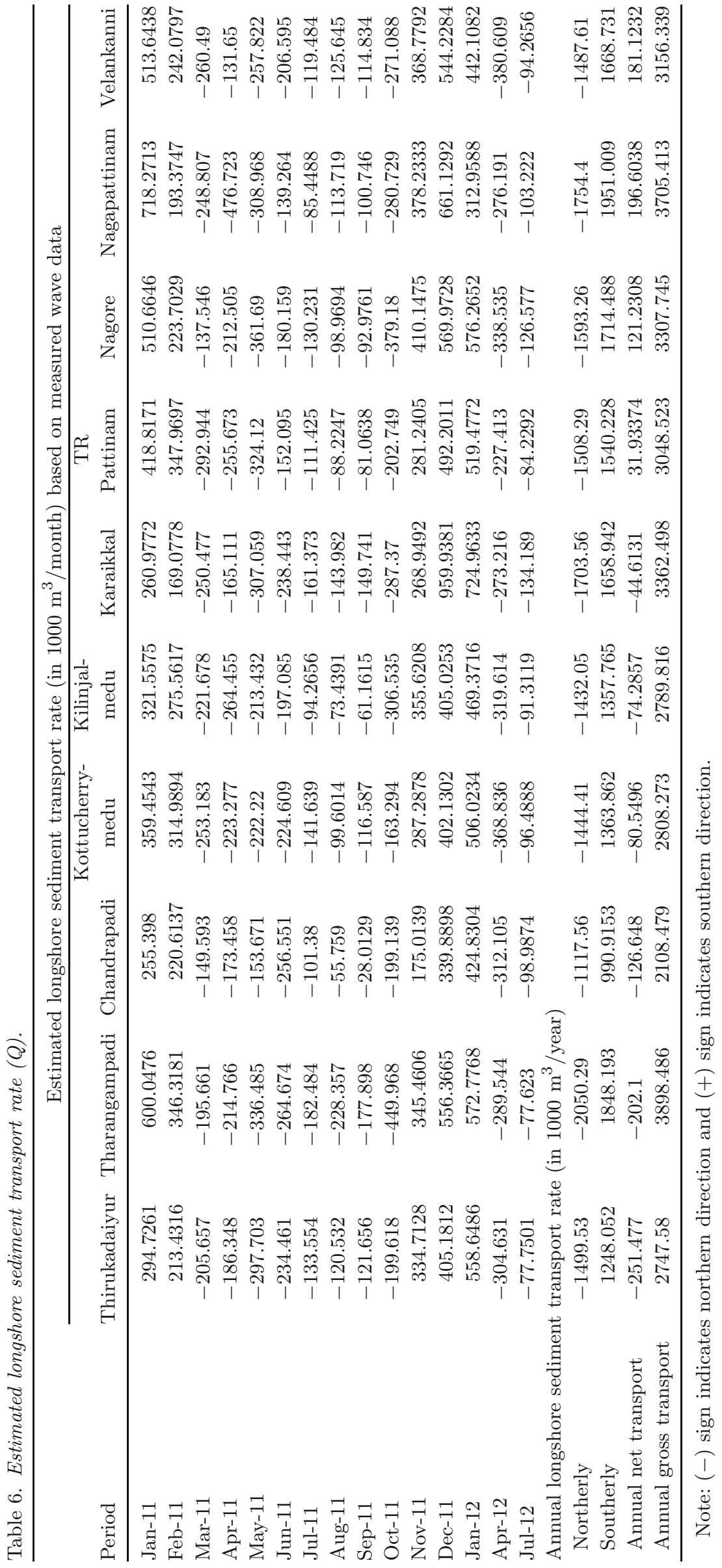




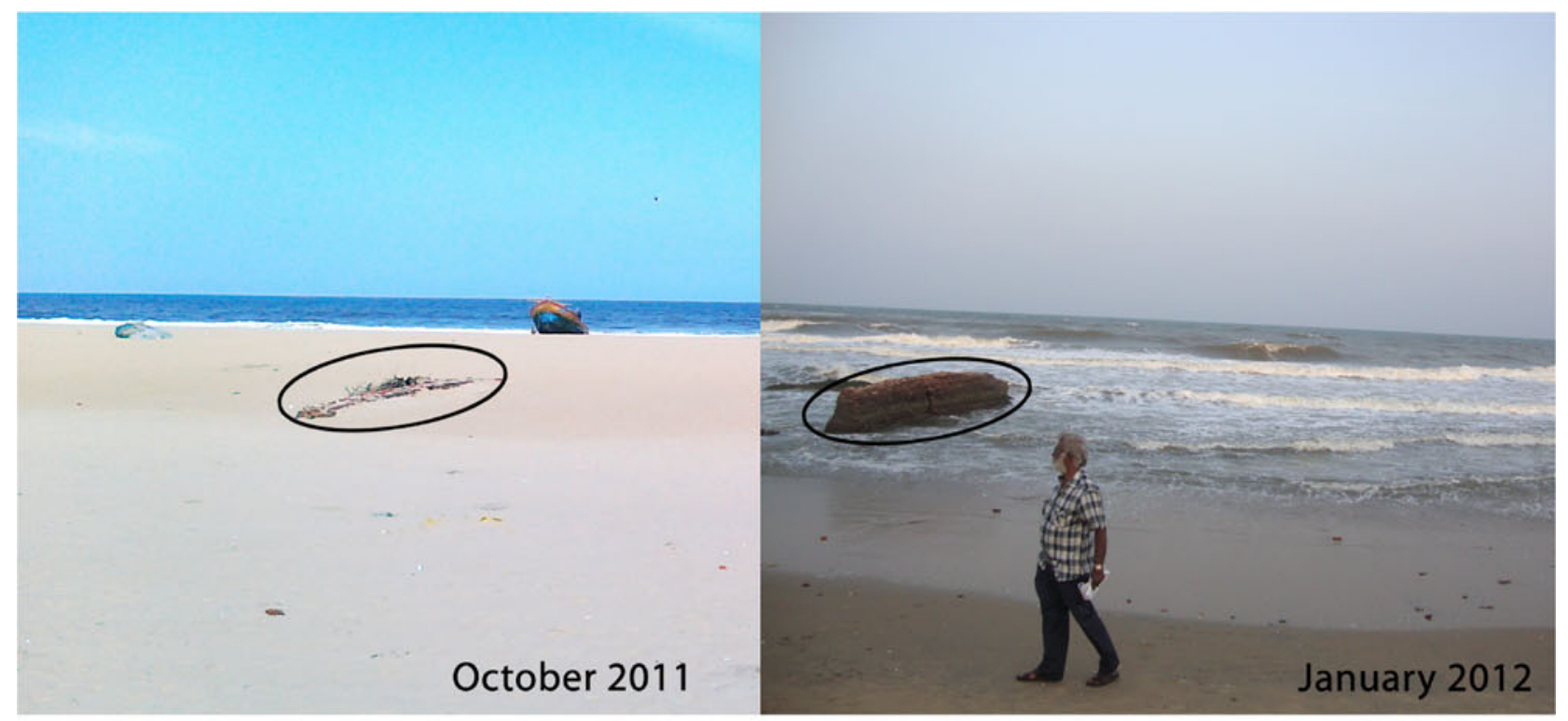

(a)

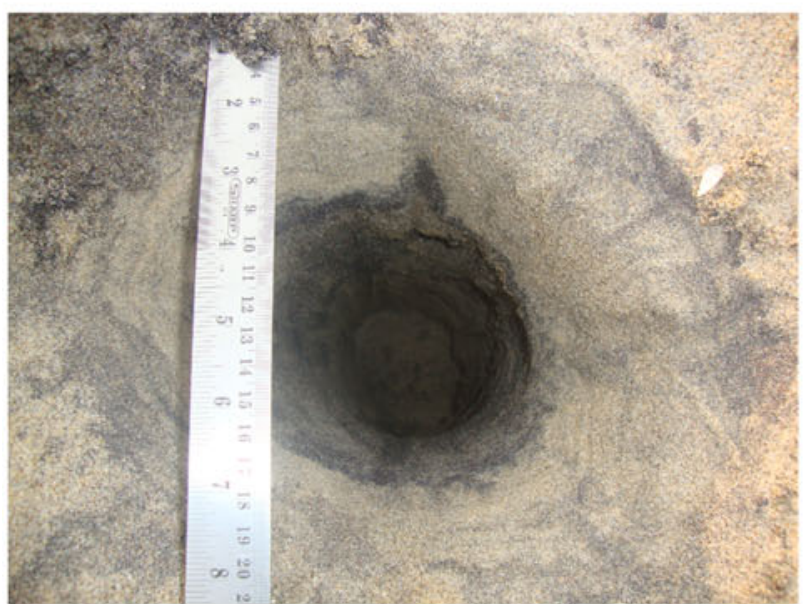

(b)

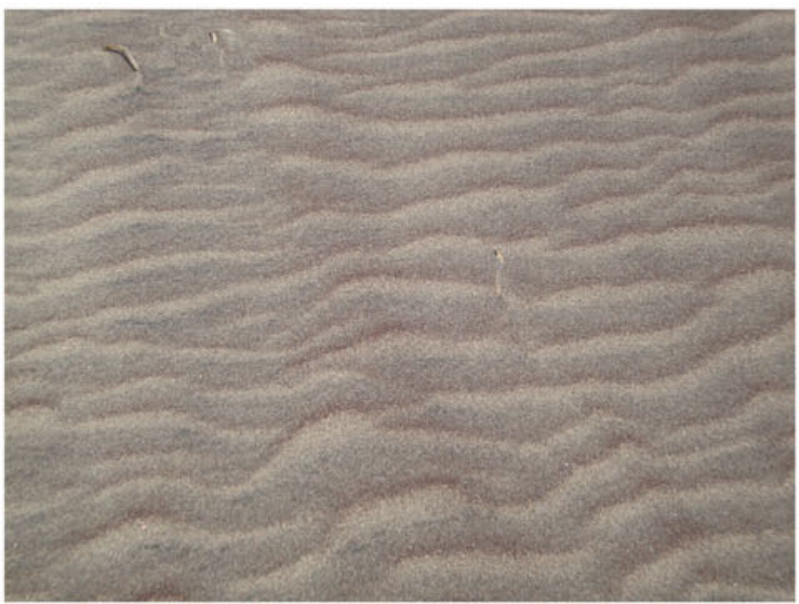

(c)

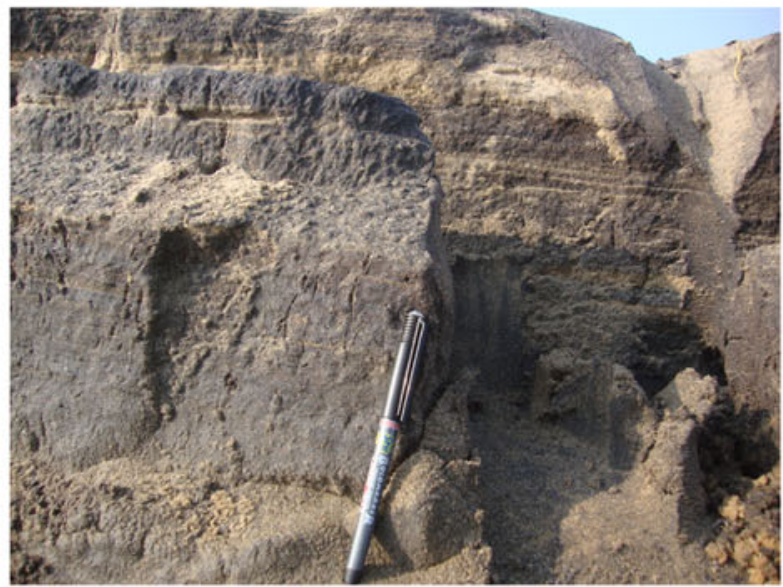

(d)

Figure 5. (a) Sediment accumulation during reflective morphodynamic state (October 2011) and erosion during dissipative morphodynamic state (January 2012). The circles are common landmark that indicates significant changes in deposition and erosion (station: Tharangampadi), (b) heavy mineral patches and lamination, (c) ripple formation of heavy mineral enriched beach sands and (d) thick lamination of heavy mineral deposition in river mouth (Kottucherrymedu). 
Table 7. Heavy mineral weight percentage in surface sediments along the study area.

\begin{tabular}{|c|c|c|c|c|c|c|c|}
\hline \multirow[b]{2}{*}{ Sl. no. } & \multirow[b]{2}{*}{ Stations } & \multicolumn{3}{|c|}{ December 2011} & \multicolumn{3}{|c|}{ January 2012} \\
\hline & & LT & $\mathrm{HT}$ & Berm & LT & HT & Berm \\
\hline 1 & Thirukadaiyur & 11.74 & 61.23 & 59.37 & 13.74 & 56.51 & 63.12 \\
\hline 2 & Tharangampadi & 3.42 & 36.19 & 23.34 & 1.6 & 32.94 & 16.6 \\
\hline 3 & Chandrapadi & 2.85 & 56.24 & 68.91 & 3.22 & 60.52 & 73.48 \\
\hline 4 & Kottucherrymedu & 1.86 & 54.35 & 66.54 & 0.24 & 58.74 & 71.84 \\
\hline 5 & Kilinjalmedu & 18.58 & 66.41 & 75.19 & 23.72 & 64.02 & 79.92 \\
\hline 6 & Karaikkal & 6.23 & 73.95 & 84.65 & 5.7 & 77.96 & 83.62 \\
\hline 7 & TR Pattinam & 8.98 & 62.17 & 56.32 & 10.28 & 61.54 & 54.38 \\
\hline 8 & Nagore & 1.2 & 57.32 & 52.12 & 0.4 & 55.78 & 46.38 \\
\hline 9 & Nagapattinam & 4.61 & 53.19 & 70.84 & 6.44 & 49 & 72.88 \\
\hline 10 & Velankanni & 9.45 & 41.23 & 51.18 & 11.02 & 36.86 & 48.16 \\
\hline
\end{tabular}

Walton and Bruno (1989) equation provides simple and generalized way to determine the longshore sediment transport.

$$
Q=\frac{1290 \times P \times g \times H_{b} \times W \times V \times C_{f}}{0.78 \times(5 \pi / 2) \times\left(V / V_{0}\right)},
$$

where $Q$ is the longshore sediment transport rate $\left(\mathrm{m}^{3} /\right.$ year $), P$ is the mass density of the sea water $\left(1025 \mathrm{~kg} / \mathrm{m}^{3}\right), g$ is the acceleration due to gravity $\left(9.8 \mathrm{~m} / \mathrm{s}^{2}\right), C_{f}$ is the friction co-efficient $(\approx 0.01)$, $H_{b}$ and $W$ are the breaking wave height $(\mathrm{m})$ and surf zone width $(\mathrm{m})$, respectively. $V$ is the measured longshore current velocity $(\mathrm{m} / \mathrm{s}), V / V_{0}$ is the theoretical dimensionless longshore current velocity $(\approx 0.4$ according to Longuet-Higgins 1970).

The estimated longshore transport rate of the entire coast is presented in table 6 . Sediment transport is northerly during April to October and southerly during November to March in the entire stretch. The sediment transport rate is relatively high exceeding $2 \times 10^{5} \mathrm{~m}^{3} /$ month during the northeast monsoon period (November-January) and relatively low about $0.1 \times 10^{5} \mathrm{~m}^{3} /$ month between March and October 2011. This represents the dynamic portion of the beach system due to wave forcing. This has been exhibited in the beach face profile. In Tharangampadi, submerged structures in the offshore is posing the greatest threats to sediment circulation and rip currents are prominent and reflected by the presence of crescentic bars, transverse bars and cuspate beaches. Therefore, the beach is highly deposited in October 2011 and largely eroded in January 2012 (figure 5a).

\subsection{Heavy mineral distribution}

Beach sands containing heavy mineral placers are found along the shoreline in the form of dissemination, patches and lamination (figure 5b). The beaches between Nagapattinam and Karaikkal have a symmetrical or asymmetrical ripple formation, and heavy mineral concentration is noticed in the troughs (figure 5c). During the non-monsoon season, a thick alluvial lamination can be seen in the river mouth (figure 5d). Heavy mineral weight percentage of surface sediment samples during December 2011-January 2012 is given in table 7 . Surface heavy mineral weight percentage in the low tide is comparatively lower than hightide and berm region. During the NE monsoon, wave backrush drops the heavy minerals resulting in heavy mineral patches settled at high-tide (HT) and mid-tide (MT) region. There is no significant change noticed in heavy mineral concentration during the period of pre- and post-Thane cyclone.

\subsubsection{XRD study}

Heavy mineral phases in sediment samples were identified using single crystal XRD instrument (Model no. PW3050/60). The samples were scanned continuously for $10-80^{\circ}$ with a step size of $0.0170(2 \theta)$. Measurement temperature was fixed at $25^{\circ} \mathrm{C}$ and Copper was used as an anode material. JCPDS-ICDD 2003 database cards were used to identify different heavy minerals present in the sediment samples. Peaks for different heavy minerals and their card numbers are as follows: Magnetite, d: 2.965, 2.097 and 1.614, JCPDS card no. 80-0390; Ilmenite, d: 2.730, 1.860 and 1.720, card no. 03-0789; Garnet, d: 2.920, 2.610, 1.560 and 1.270, card no. 02-0981; Rutile, d: 3.240, 1.683 and 1.091, card no. 78-1510; Zircon, d: 3.324, 2.541 and 1.725, card no. 81-0591. XRD plot of Nagapattinam beach sediments for the period of December 2011 and January 2012 is shown in figure 6. In both the plots, zircon peaks are much intensified. The peaks have shown that the occurrence of heavy minerals does not change but, their peak intensities are varied. It shows the stability of heavy mineral deposits even the beaches are affected by heavy storms.

\section{Discussion}

The NE and SW monsoons are the predominant cause of beach morphological changes. The higher 

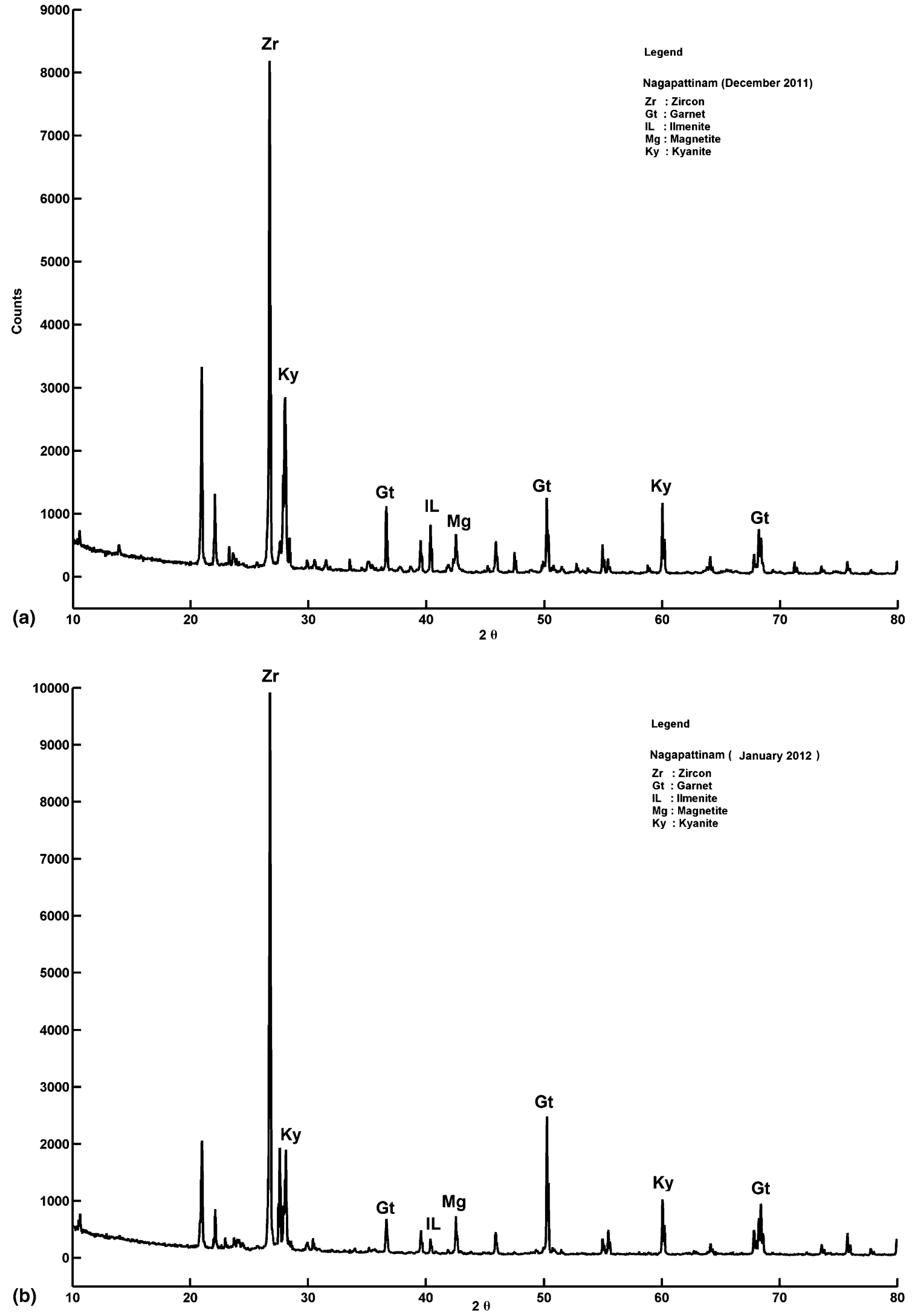

Figure 6. XRD peaks of Nagapattinam beach sediments on (a) December 2011 and (b) January 2012. 
portion of waves comes from the $\mathrm{N}$ and NE during NE monsoon producing the reversed longshore currents towards south. During this period, wave backrush carries the sediments in seaward direction, forming longshore bars at nearshore region. The coast between TR Pattinam and Velankanni has attained predominant transport rate in southern direction. The rest of the beaches have attained predominant transport rate in northern direction.

The presence of beach ridges along the coastline indicates that the present shoreline is prograding towards the sea. The continuous sediment supply by minor river system and the surf zone wave action have created an enrichment of placer deposits in the beaches between Thirukadaiyur and Velankanni. The Ilmenite dominated black sands broadly distributed in the study area can be seen by the naked eye. Although the heavy mineral concentration is found in shoreface regions, they have attained non-uniform distribution. Garnet dominates northern part of the Tharangampadi whereas, thick concentration of Ilmenite grains can be seen between Karaikkal and Nagapattinam. This is due to density sorting during sediment transport process and winnowing action of waves and currents. The Zircon deposits are primarily seen on the coast between Tharangampadi and Karaikkal. The weight percentage of heavy minerals in tidal and berm regions is evident for the redistribution of heavies even after Thane cyclone.

The wave refraction pattern for 8 and $10 \mathrm{~s}$ indicates a strong convergence wave action along the study area. But it has supplemented the low-energy environment prevailing in the region where the heavy mineral deposition is also found to be active (Chandrasekar 1992). This is being mainly controlled by coastal configuration and geomorphology of the region (Rao et al. 2001).

The entire study area has been affected by the recent tropical cyclone Thane during 25th and 30th December 2011. The response of Thane storm surge results in removal of sediments from the berm and forming it longshore bar at backshore. After the Thane surge, field investigations were made and it was found that there are no significant changes in the black sand distribution. Further, Karaikkal and Nagapattinam beaches have developed a series of berms at backshore region due to storm surge as well as cyclonic wind effect.

\section{Conclusion}

The results of this investigation reveal that the erosion and accretion events are derived by wave currents and monsoonal climate action. During the study period, it can be seen that NE monsoon created intense wave climate and storm with heavy rainfall that resulted in heavy damages in the coastal region. The beaches between Thirukadaiyur and Karaikkal have a predominant transport rate in northern direction and the rest of the beaches accomplish the same in southern direction. Thereby the beach profile indicates the strong seasonal variability in erosion at NE monsoon and accretion at SW and non-monsoon seasons. The winnowing effect of wave currents generates beach ridges and inland sediment deposits all along the coast. Nearshore wave climate displays significant changes in February and October months. The storm surge acts as a physical force to create inland deposition and sand bar formation near surf zone. River mouth/estuary appear to influence both the magnitude and characteristics of waves reworking the beach sediments. Heavy mineral weight percentage in December 2011 and January 2012 shows the intense distribution in berm region. X-ray diffraction study revealed that the heavy mineral distribution remains approximately the same even after Thane cyclone. Overall, it is concluded that seasonal action can induce the changes on beach morphology but does not affect the heavy mineral distribution.

\section{Acknowledgements}

The first author is thankful to Mr Vincent Jayaraj, $\mathrm{Mr}$ George Udayaraj, Mr Duraisamy and Mr Pushparaj for their effective support during the field survey and Mrs Xavier Leema Rose and Ms Suganya Jenifer for their help in developing the manuscript, and the support provided by the Indian Academy of Sciences, Bangalore through IASc-INSA-NASI summer research programme (SRF. No. ENGT69-2010).

\section{References}

Anil Cherian 2003 Sedimentological studies in the beaches between Valinokkam and Tuticorin, Tamil Nadu; unpublished Ph.D. thesis, Tamil University, Tamil Nadu, India.

Antonio Mascarenhas and Seelam Jayakumar 2008 An environmental perspective of post-tsunami scenario along the coast of Tamil Nadu, India: Role of sand dunes and forests; J. Environ. Manag. 89(1) 24-34.

Bascom W N 1951 The relationship between sand-size and beachface slope; Trans. Am. Geophys. Union 32 866-874.

Bijker E W 1971 Longshore transport computations, J. Waterways, Harbors and Coastal Engineering Division; American Society of Civil Engineers 97 WW4, 687-701.

Chandramohan P, Nayak B U and Anand N M 1994 Crest-breaking time-lapse approach for measuring breaking angle; J. Waterway, Port Coastal Ocean Eng. 120 318-324.

Chandrasekar N 1992 Beach placer mineral exploration along the central Tamil Nadu coast; unpublished Ph.D. 
thesis, Madurai Kamaraj University, Madurai, Tamil Nadu, India.

Chandrasekar N and Rajamanickam G V 2002 Nature of distribution of heavy minerals along the beaches of central Tamil Nadu Coast; J. Ind. Assoc. Sedimentol. 20(2) 167-180.

Chandrasekar N and Sheik Mujabar P 2010 Computer application on evaluating beach erosion and accretion from profile survey data; Comput. Geosci. 14(4) 503-508.

Chauhan O S 1995 Monsoon induced temporal changes in beach morphology and associated sediment budget at central east coast of India; J. Coast. Res. 11 767-777.

Coastal Engineering Manual 2002 U.S. Army Corps of Engineers (EM 1110-2-1100), 2nd edn, http://users. coastal.ufl.edu/ sheppard/eoc6430/Coastal_Engineering_ Manual.htm.

Cooper N J, Leggett D J and Love J P 2000 Beach profile measurement, theory and analysis: Practical guidance and applied case studies; J. Chart. Inst. Water Environ. Manag. 14(2) 79-88.

Delgado I and Lloyd G 2004 A simple low cost method for one person beach profiling; J. Coast. Res. 20(4) 1246-1252.

Folk R L and Ward W C 1957 Brazos River bar: A study in the significance of grain size parameters; J. Sedim. Petrol. 27 3-26.

Galvin C J Jr 1963 Experimental and theoretical study of longshore currents on a plane beach; Ph.D. thesis, Massachusetts Institute of Technology, Cambridge, Massachusetts.

Heitor Reis A and Cristina Gama 2010 Sand size versus beachface slope - An explanation based on the constructal law; Geomorphology 114 276-283.

King C A M 1972 Beaches and Coasts; 2nd edn, St. Martins Press, New York, pp. 1-310.

King C A M 1974 Introduction to Marine Geology and Geomorphology; Engl. Long. Soc and Edn, Arnold, London, $309 \mathrm{p}$.

Longuet-Higgins M S 1970 Longshore current generated by obliquely incident waves; J. Geophys. Res. 75(33) 6778-6801.

Loveson V J, Angusamy N, Gujar A R, Chandrasekar N and Rajamanickam G V 2008 Observed inferences from sudden changes in the sedimentological processes during the December 26, 2004 tsunami along the east coast of India; Science of Tsunami Hazards 27(4) 43-52.

Milner I 1962 Sedimentary petrology, Vol. 1 \& 2. George Allen \& Unwin Ltd., London, 643 \& 715.

Mohan P M and Rajamanickam G V 2000 Identification of coastal placer deposits along the coast between Madhuranthagam and Madras; unpubl. Technical report, Dept. of Science and Technology, New Delhi, pp. 1-180.

Mohan P M, Shepherd K, Suresh Gandhi M and Rajamanickam G V 2000 Evolution of Quaternary sediments along the coast between Vedaranyam and Rameshwaram, Tamil Nadu; J. Geol. Soc. India $\mathbf{5 6}$ 271-28.

Pickett V, Healy T R and De-Lange W P 1997 Equilibrium status of beach profiles on Bay of Plenty beaches, application of the Dean profile for coastal hazard identification; In: Combined Australian Coastal Engineering and Ports Conference, New Zealand, pp. 353-358.
Quartel S, Kroon A and Ruessink B G 2008 Seasonal accretion and erosion patterns of a microtidal sandy beach; Marine Geol. 250(1-2) 19-33.

Rajamanickam G V 1992 Heavy mineral studies of the cretaceous-Tertiary formation of Pondicherry, south India; J. Geol. Soc. India 2 234-238.

Rajamanickam M 2006 Remote sensing and GIS applications on beach placer minerals evaluation along the coast between Kallar and Vembar; Ph.D. thesis, Tamil University, Tamil Nadu, India.

Rajamanickam G V and Angusamy 2005 Exploration of placer deposits between Vedaranyam and Pondicherry, Tamil Nadu, India; Technical report, Dept. of Ocean Development, Govt. of India, New Delhi, pp. 1-220.

Rao R G, Sahoo P and Panda N K 2001 Heavy mineral sand deposit of Orissa; Exploration and Research for Atomic Minerals 13 23-52.

Revathy G, Suresh Gandhi M, Chandrasekar N and Rajamanickam G V 2002 Coastal landforms in between Nagapattinam and PortoNovo, Tamil Nadu, east coast of India; Indian J. Geomorphol. 7(1\&2) 119-133.

Sanil Kumar V, Anand N M and Gowthaman R 2002 Variation in nearshore processes along Nagapattinam coast, India; Curr. Sci. 82(11) 1381-1389.

Saxena P C, Vaidyaraman P P and Srinivasan R 1976 Design and behaviour of sand traps in regions of high littoral drift; Proc. Coast. Eng. 81 1377-1393.

Sheik Mujabar P 2010 Quantitative analysis of coastal landform dynamics between Tuticorin and Kanyakumari using remote sensing and GIS, Ph.D. thesis, Manonmaniam Sundaranar University, Tirunelveli, India.

Shore Protection Manual 1984 US Army Coastal Engineering Research Centre, Department of the Army Corps of Engineers, Washington DC.

Suresh Gandhi M and Solai A 2010 Textural and heavy mineral characteristics surface and buried sediments along the coast between Cuddalore and Pondicherry, Tamil Nadu, India; Int. J. Earth Sci. Eng. 3(6) 886-892.

Suresh Gandhi M, Solai A, Sivaraj Kaveri, Kasilingam Kanan, Venkatesan Dhamodharan, Kuppusamy Baskar and Victor Rajamanickam 2011 Post Tsunami heavy mineral distribution between Cuddalore to Kanyakumari along the Tamil Nadu Coast, India - A review; In: Tsunami - A growing disaster (ed.) Mohammad Mokhtari, pp. 189-198.

Tillotsen K J and Komar P D 1997 The wave climate of the Pacific northwest (Oregon and Washington): A comparison of data sources; J. Coast. Res. 13 440452.

Walton T L Jr and Bruno R O 1989 Longshore transport at a detached breakwater, Phase - II; J. Coast. Res. 65(9) 6778-6801.

Willis D H 1980 Evaluation of sediment transport formulae in coastal engineering practical discussion; Coast Engg. 41 177-181.

Wright L D and Short A D 1984 Morphodynamic variability of surf zones and beaches: A synthesis; Marine Geol. 56 93-118.

Wright L D, Short A D and Green M O 1985 Short-term changes in the morphodynamic states of beaches and surf zones: An empirical predictive model; Marine Geol. 62 339-364. 